\title{
PENAMBAHAN BEBERAPA JENIS BAHAN NUTRISI PADA MEDIA PERBANYAKAN UNTUK MENINGKATKAN VIRULENSI BEAUVERIA BASSIANA TERHADAP HAMA WALANG SANGIT
}

\author{
Ni Siluh Putu Nuryanti ${ }^{1}$, Lestari Wibowo ${ }^{2} \&$ Abdul Azis $^{3}$ \\ ${ }^{1}$ Jurusan Budidaya Tanaman Pangan, Politeknik Negeri Lampung \\ E-mail:siluhputu@gmail.com \\ ${ }^{2}$ Bidang Proteksi Tanaman Jurusan Agroteknologi, Fakultas Pertanian, Universitas Lampung \\ ${ }^{3}$ Jurusan Tanaman Perkebunan, Politeknik Negeri Lampung
}

\begin{abstract}
Addition of some different nutritional (materials) to the rice media for increasing virulence of Beauveria bassiana to Leptocorisa acuta. A research was conducted to increase the virulence of Beauvaria bassiana to the rice bug, $L$. acuta, by adding four different substances (materials) to the rice media to grow the fungus. The research was conducted from April to August 2011 at Polinela Laboratory, Bandar Lampung. To do this a set of experimental unit consisting of five treatments and five replications were arranged in completely randomized design. The four treatments were media made up of rice (rice based media) each given or added with four different materials such as rice skin powder, corn sugar, grasshopper powder and chitosan powder. The result showed that $B$. bassiana grown on rice media added with grasshopper powder or rice skin powder were able of causing mortality to the L. acuta as high as $78 \%$ and $71 \%$, respectively, meaning that both mortalities were much higher than that of other replication. The virulence values of Beauveria bassiana grown on those both powder were also higher than that of three others.
\end{abstract}

Key words: virulence, Beauveria bassiana, Leptocorisa acuta

\begin{abstract}
ABSTRAK
Penambahan beberapa jenis bahan nutrisi pada media perbanyakan untuk meningkatkan virulensi Beauveria bassiana terhadap hama walang sangit. Tujuan kegiatan penelitian ini adalah untuk mendapatkan teknik perbanyakan yang bisa meningkatkan virulensi Beauveria bassiana terhadap Leptocorisa acuta. Untuk mencapai tujuan tersebut dicobakan empat jenis bahan yang ditambahkan pada media perbanyakan. Percobaan terdiri dari lima perlakuan dengan lima ulangan yang disusun dalam rancangan acak lengkap. Bahan-bahan yang ditambahkan pada media perbanyakan yaitu tepung dedak, gula jagung, tepung belalang, dan tepung kulit udang. Media perbanyakan yang digunakan adalah beras. Hasil penelitian menunjukkan bahwa jamur B. bassiana yang ditumbuhkan pada media beras dengan penambahan tepung belalang atau tepung dedak, mampu menyebabkan mortalitas walang sangit sebesar $78 \%$ dan $71 \%$. Nilai virulensi B. bassiana - walang sangit pada perlakuan penambahan tepung belalang atau dedak secara nyata lebih tinggi dibandingkan dengan perlakuan taimma.
\end{abstract}

Kata kunci: virulensi, Beauveria bassiana, Leptocorisa acuta

\section{PENDAHULUAN}

Penggunaan insektisida sintetik sebagai pengendali hama telah menimbulkan beberapa masalah seperti munculnya ketahanan hama terhadap insektisida, resurjensi hama, letusan hama kedua, dan berkurangnya musuh alami hama (Oka, 1998; Untung, 2001). Perlu dicari alternatif lain untuk pengendalian hama, seperti penggunaan jamur entomopatogen sebagai agens hayati pengendali hama. Ada beberapa alasan mengapa jamur entomopatogen menjadi pilihan untuk pengendalian hama. Alasan tersebut diantaranya adalah jamur entomopatogen mempunyai kapasitas reproduksi yang tinggi, siklus hidup yang pendek, dapat membentuk spora yang dapat bertahan lama di alam, bahkan dalam kondisi yang tidak menguntungkan sekalipun (Soetopo \& Indriyani, 2007). Penggunaan jamur entomopatogen juga relatif aman, bersifat selektif, kompatibel dengan berbagai komponen pengendalian dalam PHT, relatif mudah diproduksi, dan kemungkinan menimbulkan resistensi sangat kecil (Widayat \& Rayati, 1991). Salah satu jamur entomopatogen yang sudah teruji memiliki potensi untuk pengendalian hama yaitu Beauveria bassiana (Suharto et al., 1998; Soetopo, 2004). 
Kondisi iklim di Indonesia, khususnya di berbagai agroekosistem dengan curah hujan yang cukup pertahunnya sangat potensial mendukung inisiasi dan perkembangan epizootik jamur entomopatogen, khususnya $B$. bassiana. Hal tersebut berkaitan dengan tingkat kelembapan tinggi dan temperatur rendah yang cenderung konsisten sepanjang tahun merupakan lingkungan ideal bagi jamur entomopatogen. Dukungan ekosistem dan faktor abiotik (kelembapan dan temperatur) yang ideal merupakan modal awal upaya pengembangan B.bassiana (Haryono et al., 1993).

Di samping faktor lingkungan, pengetahuan yang berkaitan dengan B. bassiana sebagai agen hayati, termasuk faktor-faktor teknis seperti mekanisme infeksi, kemampuan membunuh, durasi mematikan hama sasaran, dan teknik produksi dan aplikasi juga perlu dikaji dan diteliti. Beberapa upaya yang perlu dilakukan untuk meningkatkan pemanfaatan B. bassiana dalam pengendalian serangga hama antara lain mendapatkan isolat lokal yang tepat, meningkatkan kualitas dan patogenisitas jamur, meningkatkan metode perbanyakan dan aplikasi jamur entomopatogen untuk pengendalian hama, serta teknik formulasi produk agar mudah digunakan dengan kualitas yang terjaga.

Prospek pengembangan agen hayati ini pada komoditas tanaman pangan, hortikultura, dan tanaman perkebunan cukup baik karena didukung oleh iklim mikro pertanaman yang sangat sesuai bagi perkembangan epizootik $B$. bassiana. Selain itu, biaya pengendalian dengan bioinsektisida ini akan cenderung lebih murah dibanding dengan insektisida kimiawi sintetik. Ketersediaan teknologi produksi dan isolat lokal yang virulen dan potensial akan mendukung program pengembangannya pada masa mendatang.

Di Indonesia pengkajian tentang pemanfaatan $B$. bassiana dalam pengendalian hama cukup pesat. Penelitian uji potensi dan efektivitas baik di laboratorium maupun lapang juga telah dilakukan. Efektivitas $B$. bassiana telah diuji terhadap hama kelapa Brontispa longissima (Hosang, 1995). Pada tahun 1993 jamur ini juga telah digunakan secara luas untuk mengendalikan penggerek buah kakao Conoponorpha cramerella di daerah Aceh, Sumatera Utara, Lampung, Jawa Timur dan Timor Timur (Haryono et al., 1993). Potensi $B$. bassiana dalam pengendalian dua spesies rayap, Nasutitermes dan Coptotermes curvignathus yang menyerang tanaman murbei di Sulawesi Selatan juga cukup tinggi. Kematian hama ini mencapai $100 \%$ pada dosis 1,4 x 10 $0^{5} \mathrm{konidia} / \mathrm{ml}$ (Saranga, 1997).

Jamur B.bassiana mudah diperbanyak secara in vitro, namun ternyata dalam proses perbanyakan secara in vitro dapat terjadi penurunan kualitas dan virulensinya (Herlinda et al., 2006). Penurunan kualitas spora jamur entomopatogen dapat disebabkan karena berkurangnya sumber karbon, khitin, pati, dan protein pada media perbanyakan (Tanada \& Kaya, 1993; Rosalind, 2000). Oleh karena itu sangat diperlukan teknik perbanyakan dan cara aplikasi yang bisa mempertahankan kualitas, dan patogenisitas jamur. Teknik perbanyakan jamur entomopatogen yang akan dicobakan yaitu dengan menambahkan beberapa jenis nutrisi ke dalam beras sebagai media perbanyakan. Bahan tambahan tersebut seperti dedak, gula jagung, tepung serangga dari hama belalang (Locusta migratoria), dan tepung kulit udang.

Tujuan penelitian ini adalah untuk mengetahui pengaruh penambahan beberapa jenis bahan nutrisi pada media perbanyakan dalam meningkatkan kualitas pertumbuhan jamur dan virulensi $B$. bassiana terhadap walang sangit ( L. acuta).

\section{METODE PENELITIAN}

Tempat dan Waktu. Penelitian dilakukan di kebun percobaan, rumah kaca, dan Laboratorium Produksi Tanaman I Kampus Politeknik Negeri Lampung. Penelitian dilakukan dari Juni sampai November 2011.

Persiapan Serangga Uji. Walang sangit sebagai serangga uji diperoleh dari lahan sawah desa Rajabasa Jaya, kemudian dipelihara dan dibiakkan pada tanaman padi dalam sungkup di rumah kaca hingga diperoleh jumlah yang cukup. Walang sangit yang digunakan saat aplikasi adalah nimfa instar 5.

Persiapan Isolat B. bassiana. Inokulum $B$. bassiana diperoleh dari serangga (larva Lepidoptera) mati terinfeksi $B$. bassiana yang ditemukan di lahan pertanian sentra sayuran di Kecamatan Gisting Kabupaten Tanggamus. Sebelum digunakan terlebih dahulu dilakukan isolasi dan pemurnian terhadap jamur $B$. bassiana pada media PDA di laboratorium. Setelah diperoleh biakan murni, kemudian B. bassiana ditumbuhkan pada media beras. Hasil biakan ini digunakan sebagai starter.

Proses pembuatan starter yaitu beras ditimbang dan dicuci bersih, selanjutnya dikukus dengan menggunakan dandang selama 30 menit ( $1 / 2$ matang). Beras yang telah dikukus dihamparkan di atas nampan sampai dingin. Setelah itu beras dimasukkan ke dalam kantong plastik tahan panas masing-masing 100 gram. Selanjutnya beras dalam kantung plastik tersebut disterilkan pada autoclave dengan temperatur $121^{\circ} \mathrm{C}$, tekanan 15 psi dan dikonstankan selama 60 menit, lalu 
diangkat dan didinginkan. Pada media beras yang steril tersebut dilakukan inokulasi isolat murni agen hayati dengan menggunakan pinset steril. Selanjutnya plastik dikocok agar spora jamur dapat tersebar merata pada media beras, kemudian diinkubasikan pada suhu kamar selama \pm 2 minggu.

Perbanyakan massal B. bassiana dilakukan dengan proses yang sama seperti pembuatan starter, hanya tidak menggunakan inokulasi isolat murni melainkan menggunakan starter inokulum dengan perbandingan satu bagian starter untuk 10 bagian media perbanyakan. Perlakuan adalah: (P1) media perbanyakan beras saja, (P2) media perbanyakan beras yang ditambahi 1,5\% dedak, (P3) media perbanyakan beras yang ditambahi $1,5 \%$ gula jagung, (P4) media perbanyakan beras yang ditambahi $1,5 \%$ tepung belalang, dan P5) media perbanyakan beras yang ditambahi $1,5 \%$ tepung kulit udang.

Penelitian ini terdiri dari dua set percobaan yang masing-masing disusun dalam Rancangan Acak Lengkap dengan lima perlakuan dan lima ulangan. Set pertama adalah aplikasi dengan metode kontak (pada metode ini serangga uji dicelupkan selama tiga detik pada larutan uji). Sedangkan set kedua adalah aplikasi dengan metode pakan (pada metode ini pakan serangga yang dicelupkan selama lima detik ke dalam larutan uji). Setiap satuan percobaan menggunakan serangga uji walang sangit sejumlah 20 ekor.

Pembuatan Larutan Uji. Larutan uji dibuat dengan cara mengambil 10 gram media biakan yang telah ditumbuhi B. Bassiana, dilumatkan lalu campurkan ke dalam $200 \mathrm{ml}$ aquades, kemudian diaduk hingga rata dengan menggunakan rotamixer. Selanjutnya campuran tersebut disaring untuk diaplikasikan dalam pengujan.

Pengamatan. Pengamatan dilakukan setiap 12 jam selama 8 hari setelah aplikasi. Pengamatan meliputi mortalitas serangga uji, waktu kematian, selanjutnya dihitung periode letal $B$. bassiana pada masing-masing serangga uji dari setiap perlakuan. Pengamatan juga dilakukan terhadap gejala penyakit pada serangga uji, serta pengamatan di bawah mikroskop untuk pembuktian kematian serangga karena infeksi $B$. bassiana. Persentase mortalitas serangga uji dihitung dengan rumus $\mathrm{P}=\mathrm{A} / \mathrm{B} \times 100 \%$, dengan $\mathrm{P}=$ persentase kematian serangga uji; $A=$ jumlah serangga uji mati selama 8 hari pengamatan; $\mathrm{B}=$ jumlah serangga uji awal per unit percobaan. Tingkat virulensi dihitung dengan menggunakan rumus (Susilo et al., 1993).

$$
\delta=\frac{1}{T} \operatorname{dan} T=\frac{\Sigma(H i)(M i)}{\Sigma(M i)}
$$

dengan

$\mathrm{T}=$ periode letal rata-rata

$\mathrm{Hi}=$ waktu kematian (periode letal individu serangga uji)

Mi $=$ jumlah serangga yang mati (terinfeksi)

Untuk mengetahui pengaruh teknik perbanyakan dengan penambahan beberapa bahan terhadap spora jamur B. bassiana, maka dilakukan pengitungan jumlah spora. Penghitungan jumlah spora dilakukan dengan beberapa langkah. Langkah pertama adalah jamur entomopatogen dari masing-masing teknik perbanyakan ditimbang sebanyak 1 gram. Lalu jamur yang telah ditimbang tersebut dicampur aquades sebanyak $100 \mathrm{ml}$ kemudian dihancurkan/dilumatkan, lalu disaring sehingga didapat suspensi spora jamur. Langkah selanjutnya yaitu, ruang hitung Haemacytometer ditutup dengan kaca obyek dan diteteskan suspensi sebanyak $1 \mathrm{cc}$ dengan pipet tetes, sehingga suspensi mengalir ke bawah kaca obyek dan ruang hitungpun dapat terisi. Terakhir, jumlah spora dihitung dalam lima kotak besar yang masingmasing dilakukan di bawah mikroskop, penghitungan diulang 2 kali. Jumlah spora dicatat dan dihitung dengan rumus:

$$
J=\frac{t x d}{0,25 x n} \times 10^{6} \text { spora } / \mathrm{ml}
$$

dengan:

$\mathrm{J}=$ jumlah spora dalam satu gram media

$\mathrm{t}=$ jumlah spora dalam semua kotak bujur sangkar yang dihitung

$\mathrm{d}=$ faktor pengenceran bila harus diencerkan $(\mathrm{d}=1$

berarti tidak diencerkan; $\mathrm{d}=10$ berarti diencerkan 1 $: 10)$

$0,25=$ kostanta

$\mathrm{n}=$ jumlah kotak bujur sangkar yang dihitung

Analisis Data. Data hasil pengamatan yang berupa persentase mortalitas, periode periode letal, dan jumlah spora jamur $B$. bassiana dianalisis dengan sidik ragam dan perbedaan nilai tengah antarperlakuan diuji dengan Uji Beda Nyata Terkecil (BNT). Semua uji menggunakan taraf nyata $5 \%$.

\section{HASIL DAN PEMBAHASAN}

Mortalitas Walang Sangit. Hasil pengamatan menunjukkan aplikasi jamur B. Bassiana secara nyata berpengaruh terhadap mortalitas walang sangit. Pada 
Tabel 1. Mortalitas walang sangit setelah aplikasi jamur B. bassiana yang ditumbuhkan pada media beras dengan penambahan beberapa jenis bahan dan aplikasi dengan metode kontak dan residu pakan

\begin{tabular}{lcc}
\hline \multirow{2}{*}{ Perlakuan } & \multicolumn{2}{c}{ Mortalitas $(\%)$} \\
\cline { 2 - 3 } & Metode kontak & Metode residu pakan \\
\hline P1 = Media perbanyakan beras saja & $58 \mathrm{c}$ & 16 \\
P2 = Media beras + 1,5\% dedak & $71 \mathrm{~b}$ & 17 \\
P3 = Media beras + 1,5\% gula jagung & $49 \mathrm{~d}$ & 14 \\
P4 = Media beras + 1,5\% tepung belalang & $78 \mathrm{a}$ & 18 \\
P5 = Media beras + 1,5\% tepung kulit udang & $54 \mathrm{~cd}$ & 15 \\
\hline BNT $_{0,05}$ & 6,41 & $\left(\mathrm{~F}_{\text {hit }}=1,83^{\text {tn }}\right)$ \\
\hline
\end{tabular}

Angka pada kolom yang sama diikuti oleh huruf yang sama tidak berbeda nyata menurut uji BNT (p>0,05)
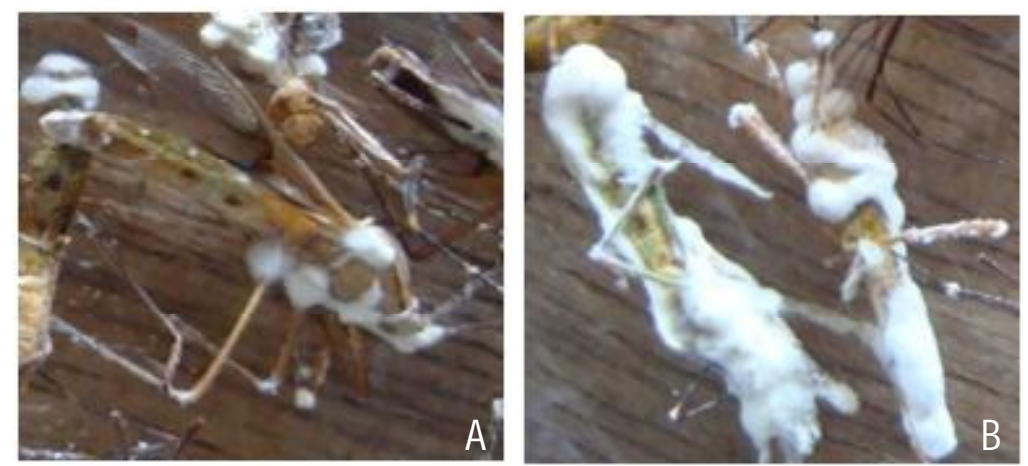

Gambar 1. Pertumbuhan hifa jamur B.bassiana pada sebagian tubuh walang sangit (A), hifa jamur $B$. bassiana menutupi seluruh tubuh walang sangit (B).

set percobaan dengan metode kontak mortalitas walang sangit yang terjadi cukup tinggi, sedangkan pada metode aplikasi residu pakan, mortalitas walang sangit rendah tidak mencapai $20 \%$. Data mortalitas walang sangit terlihat pada Tabel 1. Pada set percobaan pertama, di mana pada saat aplikasi tubuh walang sangit secara langsung terkena kontak dengan suspensi spora $B$. bassiana, menyebabkan terjadinya mortalitas walang sangit akibat terinfeksi B.bassiana yang cukup tinggi. Kematian mulai terjadi sejak hari ke 2 setelah aplikasi.

Penambahan bahan pada media beras sebagai media perbanyakan B. bassiana, berpengaruh pada mortalitas serangga uji. B. bassiana yang ditumbuhkan pada media beras dengan penambahan tepung belalang (P4) secara nyata menyebabkan mortalitas walang sangit tertinggi (78\%), disusul perlakuan penembahan tepung dedak (P2) dengan mortalitas walang sangit mencapai $71 \%$. Penambahan tepung belalang dan dedak pada media beras ternyata meningkatkan kemampuan B. bassiana dalam menyebabkan mortalitas walang sangit. Tepung dedak mengandung karbohidrat, protein, dan vitamin B yang merupakan sumber nutrisi dan energi yang sangat dibutuhkan dalam pertumbuhan jamur B.bassiana. Tepung belalang banyak mengandung kitin dan protein. Hasil penelitian Herlinda (2006) menunjukkan penambahan bahan yang mengandung kitin dan protein seperti tepung jangkrik pada media biakan dapat merangsang $B$. bassiana menghasilkan enzim khitinase. Samsinakova et al. (1971) melaporkan $B$. bassiana menghasilkan enzim khitinase yang mampu mendegradasi khitin pada kutikula serangga. Dengan demikian, peningkatan kemampuan B. bassiana membunuh walang sangit disebabkan adanya peningkatan enzim kitinase yang mendegradasi kutikula dan kitin serangga uji pada proses infeksi.

Walang sangit yang terinfeksi $B$. bassiana menunjukkan gejala berkurangnya aktivitas gerak dan makan, selanjutnya walang sangit terjatuh ke dasar stoples meskipun belum mengalami kematian. Beberapa waktu kemudian walang sangit mengalami kematian ditandai dengan tubuhnya yang kaku dan warna tubuhnya menjadi kusam. Untuk memastikan bahwa kematian 
karena terifeksi $B$. bassiana, maka tubuh walang sangit yang telah mati diletakkan pada tempat yang lembab yaitu di atas kertas saring yang telah dibasahi. Keesokan harinya terlihat tubuh walang sangit yang mati karena terinfesi $B$. bassiana ditumbuhi oleh hifa jamur $B$. bassiana yang berwarna putih. Pada awalnya pertumbuhan hifa jamur terutama pada bagian lipatan kutikula antar ruas tubuh (Gambar 1a), selanjutnya hifa berkembang menutupi permukaan tubuh walang sangit (Gambar 1b).

Pada set percobaan ke dua, malai padi sebagai pakan dicelupkan pada suspensi spora B. bassiana, mortalitas walang sangit juga terjadi namun dengan persentase yang rendah yaitu tidak mencapai $20 \%$. Kematian mulai terjadi pada hari ke tiga setelah aplikasi. Spora B. bassiana yang ada pada malai dapat berkontak dan menempel pada permukaan tubuh walang sangit selanjutnya menimbulkan infeksi. Rendahnya mortalitas walang sangit pada set percobaan kedua dikarenakan potensi kontak spora $B$. bassiana yang ada pada malai padi dengan tubuh walang sangit rendah. Berbeda dengan pada set percobaan pertama, di mana tubuh walang sangit secara langsung terkena kontak dengan suspensi spora $B$. bassiana. Kontak antara spora $B$. bassiana dan tubuh walang sangit akibat pencelupan tersebut lebih besar sehingga menyebabkan infeksi yang lebih tinggi. Besarnya (potensi) kontak berbanding lurus dengan daya infeksi patogen (Dewi et al., 1998). Jamur $B$. bassiana menginfeksi serangga inangnya setelah spora jamur yang berkontak (menempel) pada bagian kutikula berkecambah dan menembus kutikula serangga inang (Shepard et al., 1987). Penembusan ke dalam kutikula serangga oleh kecambah spora dilakukan secara mekanis dan kimiawi dengan mengeluarkan enzim dan toksin (Tanada \& Kaya, 1993). Kemudian patogen berkembang biak di dalam tubuh serangga hingga dapat menyebabkan kematian seranga.

Mekanisme infeksi diawali dengan invasi, yaitu masuknya patogen ke dalam tubuh serangga inang. Kemudian patogen berkembang biak di dalam tubuh serangga. Invasi mengalami akselerasi dan mencapai klimaks pada puncak infeksi dan berakhir dengan kematian serangga. Dengan andaian bahwa invasi terjadi segera setelah inokulasi, maka jangka waktu sejak inokulasi sampai terjadinya kematian serangga dapat ditentukan sebagai periode letal patosistem (Susilo et al., 1993).

Periode Letal $B$. bassiana. Pada set percobaan pertama dengan metode aplikasi kontak (insect-dip bioassay), mortalitas serangga uji terjadi pada kisaran waktu 2-6 hari. Rata-rata hari kematian serangga merupakan periode letal B. bassiana, yaitu berkisar antara 3,73-4,17 hari. Penambahan bahan-bahan nutrisi lain pada media perbanyakan ternyata tidak berpengaruh pada periode letal $B$. bassiana - walang sangit. Indriyati (2009) melaporkan bahwa periode letal B. bassiana terhadap kepik hijau (Nezara viridula) yaitu berkisar antara 4,58-5,44 hari, sedangkan terhadap kutu daun (Aphis spp.) lama periode letal yaitu 3,70 hari. Adanya perbedaan waktu periode letal $B$. bassiana, terhadap walang sangit, kepik hijau, dan kutu daun mengarah pada fenomena adanya perbedaan respon dari serangga inang (Tohidin et al., 1993; Sabbahi et al.,2008).

Pada set percobaan kedua malai padi sebagai pakan dicelupkan pada suspensi spora $B$. bassiana, walang sangit mengalami kematian dalam waktu 4,895,40 hari. Waktu kematian yang lebih lama pada set percobaan ini dikarenakan spora B. bassiana tidak

Tabel 2. Virulensi B. bassiana yang ditumbuhkan pada media beras dengan penambahan beberapa jenis bahan pada teknik aplikasi metode kontak dan residu pakan terhadap walang sangit

\begin{tabular}{lcc}
\hline \multicolumn{1}{c}{ Perlakuan } & \multicolumn{2}{c}{ Virulensi } \\
\cline { 2 - 3 } & Metode Kontak & Metode residu pakan \\
\hline P1 = Media perbanyakan beras saja & $0,261 \mathrm{~b}$ & $0,193 \mathrm{bc}$ \\
P2 = Media beras + 1,5\% dedak & $0,264 \mathrm{a}$ & $0,189 \mathrm{~cd}$ \\
P3 = Media beras + 1,5\% gula jagung & $0,239 \mathrm{c}$ & $0,185 \mathrm{~d}$ \\
P4 = Media beras + 1,5\% tepung belalang & $0,268 \mathrm{a}$ & $0,201 \mathrm{a}$ \\
P5 = Media beras + 1,5\% tepung kulit udang & $0,256 \mathrm{~b}$ & $0.195 \mathrm{~b}$ \\
\hline BNT $_{0,05}$ & 0,0062 & 0,0051 \\
\hline
\end{tabular}

Angka pada kolom yang sama diikuti oleh huruf yang sama tidak berbeda nyata menurut uji BNT $(\mathrm{p}>0,05)$ 
langsung melekat pada tubuh walang sangit pada saat aplikasi.

Kebalikan (inverse) dari periode letal merupakan nilai virulensi patogen tersebut (Susilo et al., 1993). Nilai virulensi $B$. bassiana - walang sangit dipengaruhi oleh perlakuan penambahan bahan pada media perbanyakan. Jamur B. bassiana yang ditumbuhkan pada media beras dengan perlakuan penambahan tepung belalang dan dedak secara nyata memiliki virulensi lebih tinggi dibandingkan dengan perlakuan lainnya. Nilai virulensi B. bassiana yang ditumbuhkan pada media beras dengan diberi tambahan tepung belalang adalah sebesar 0,268 , yang berarti bahwa B. bassiana mampu menginfeksi 0,26 bagian tubuh walang sangit setiap harinya hingga menyebabkan kematian pada hari ke 3,73 setelah inokulasi (nilai periode letal rata-rata pada $\mathrm{P} 4$ ) (Tabel 2).

Jumlah Spora B. Bassiana. Dari hasil analisis ragam, rata-rata jumlah spora $B$. bassiana pada kelima perlakuan diketahui tidak berbeda nyata. Rata-rata jumlah spora B. bassiana berkisar $23,8 \times 10^{7} \mathrm{spora} / \mathrm{ml}$ sampai dengan $26,1 \times 10^{7} \mathrm{spora} / \mathrm{ml}$. Terlihat pada ke lima perlakuan, media yang digunakan untuk perbanyakan memiliki nutrisi yang cukup untuk pertumbuhan $B$. bassiana. Meskipun penambahan beberapa jenis bahan pada media biakan tidak menyebabkan perbedaan jumlah spora, namun dari penelitian ini terlihat perlakuan penambahan tepung belalang dan dedak dapat meningkatkan kemampuan B.bassiana dalam membunuh walang sangit.

\section{SIMPULAN}

Dari hasil penelitian ini dapat disimpulkan bahwa jamur B. bassiana yang ditumbuhkan pada media beras dengan penambahan tepung belalang atau tepung dedak, mampu menyebabkan mortalitas walang sangit sebesar $78 \%$ dan $71 \%$. Nilai tersebut lebih tinggi dibandingkan dengan mortalitas pada perlakuan lainnya. Nilai virulensi B. bassiana - walang sangit pada perlakuan penambahan tepung belalang atau dedak secara nyata lebih tinggi dibandingkan dengan perlakuan lainnya. Inokulasi B.bassiana menggunakan metode residu pakan tidak efektif, di mana mortalitas walang sangit relatif rendah tidak mencapai $20 \%$. Penambahan beberapa jenis bahan pada media biakan tidak menyebabkan perbedaan jumlah spora $B$. bassiana.

\section{DAFTAR PUSTAKA}

Dewi M, Susilo FX \& Hariri AM. 1998. Daya infeksi, efisiensi penularan, dan periode lethal penyakit muskardin hijau (Metarhizium anisopliae) pada wereng batang coklat padi (Nilaparvata lugens). Jurnal Penelitian Pertanian 9 (9): 156-166.

Haryono H, Nuraini S \& Riyanto.1993. Prospek penggunaan Beauveria bassiana untuk pengendalian hama tanaman perkebunan.hlm. 7581 Dalam: Prosiding Makalah Simposium Patologi Serangga I. Yogyakarta, 12-13 Oktober 1993.

Herlinda S, Muhamad DU, Yulia P \& Suwandi. 2006. Kerapatan dan viabilitas spora Beauveria bassiana akibat subkultur dan pengayaan media, serta virulensinya terhadap larva Plutella xylostella(Linn.). JHPT. Tropika 6(2): 70-78.

Hosang MLA. 1995. Patogenitas cendawan Beauveria bassiana (Bals.) Vuill terhadap Brontispa longissima Gestro (Coleoptera: Hispidae). Thesis S2 (Tidak dipublikasi). Institut Pertanian Bogor (IPB), 66 hlm.

Indriyati. 2009. Virulensi jamur entomopatogen Beauveria bassiana (Bals.)Vuill terhadap kutu daun (Aphis spp.) dan kepik hijau (Nezara viridula). JHPT. Tropika 9(2): 92-98.

Oka IN. 1998. Pengendalian Hama Terpadu dan Implementasinya di Indonesia. Gadjah Mada University Press. Yoyakarta.

Rosalind R. 2000. The Effect of Certain Nutrients on Conidial Germination of Beauveria bassiana and Paecilomyces jumosoroseus. USDA: Agricultural Research Service, Tekran.

Sabbahi R, Merzouki A \& Guertin C. 2008. Efficacy of Beauveria bassiana against the strawberry pest, Lygus lineolaris, Anthonomus signatus and Otiorhynchus ovatus. J. Appl. Entomology 132(2):151-160.

Saranga AP. 1997. Uji pemanfaatan jamur Beauveria bassiana Vuill. Hypomycetes: Moniliales) pada dua spesies rayap (Isoptera). hlm. 1-14 Dalam: Prosiding Makalah Pendukung Seminar Nasional Pengendalian Hayati, Yogyakarta 25-26 November 1996. 
Samsinakova A, Misikova S \& Leopold J. 1971. Action of enzymatic system of Beauveria bassiana on cuticle of the greater wax moth larvae (Galleria mellonella). J. Invert. Pathol. 18:322-330.

Shepard BM, Barion AT \& Litsinger JA. 1987. Helpful Insects, Spiders, and Pathogen. IRRI, Los Banos. 136 pp

Soetopo D. 2004. Effecacy of Selected Beauveria bassiana (Bals.) Vuill. Isolates in Combination With a Resistant Cotton Variety (PSB-Ct 9) Againts the Cotton Bollworm, Helicoverpa armigera (Hubner) (Lepidoptera: Noctuidae). Disertasi, Philippines: University of the Philippines Los Banos.

Soetopo D \& Indriyani. 2007. Status teknologi dan prospek Beauveria bassiana untuk pengendalian serangga hama tanaman perkebunan yang ramah lingkungan. Perspektif 6(1): 29-46 http:// perkebunan litbang.go.id/publikasi/perspektif. Dakses tanggal 5 Agustus 2009.

Suharto EB, Trisusilowati \& Purnomo H. 1998. Kajian aspek fisiologi Beauveria bassiana dan virulensinya terhadap Helicoverpa armigera. $J$. Perlin. Tan. Indonesia. 4: 112-119.
Susilo FX, Hasibuan R, Nordin GL \& Brown GC. 1993. The concept of threshold density in insect pathology: A Theoretical and experimental study on Tetranychus - Neozygites mycosis. Prosiding Makalah Simposium Patologi Serangga I. Yogyakarta, 12-13 Oktober 1993. Hlm. 29-37.

Tanada Y \& Kaya HK. 1993. Insect Pathology. Academic Press Boston. Pp. 595-612.

Tohidin A, Lisriantu T \& Machdar BP. 1993. Daya bunuh jamur entomopatogen Beauveria bassiana (Bals.) Vuill terhadap Leptocorisa acuta di rumah kaca. Dalam Prosiding Makalah Simposium Patologi Serangga I. Yogyakarta, 12-13 Oktober 1993. Hlm. 135-143.

Untung K. 2001. Pengantar Pengolahan Hama Terpadu. Gadjah Mada University Press. Yogyakarta. $273 \mathrm{hlm}$.

Widayat W \& Rayati DJ. 1991. Daya Bunuh Spora Jamur Entomopatogenik terhadap Ulat Jengkal (Boarmia bhurmitra) hama Tanaman Kina in Vitro. Dalam Prosiding Kongres Nasional XI dan Seminar Ilmiah PFI. Ujung Pandang, 2426 September 1991. P. 147-150. 